\title{
Incorporation of fluorophosphate into zinc-aluminium-nitrate layered double hydroxide by ion exchange
}

\author{
EL HASSAN ELKHATTABI, MOHAMED BADREDDINE ${ }^{\dagger}$, MOHA BERRAHO \\ and AHMED LEGROURI ${ }^{\ddagger}$,* \\ Laboratoire de Chimie Biomoléculaire, Substances Naturelles et Réactivités, Unité des Matériaux, \\ Faculté des Sciences Semlalia, Université Cadi Ayyad, BP 2390, Marrakech 40000, Morocco \\ $\dagger$ Centre des Classes Préparatoires Ibnou Taimya, Route d’Essaouira, Marrakech 40000, Morocco \\ ${ }^{\ddagger}$ School of Science and Engineering, Al Akhawayn University, PO Box 104, Ifrane 53000, Morocco
}

MS received 7 May 2011; revised 11 October 2011

\begin{abstract}
The intercalation of fluorophosphate $\left(\mathrm{PO}_{3} \mathrm{~F}^{2-}, \mathrm{FP}\right)$ in the $[\mathrm{Zn}-\mathrm{Al}]$ layered double hydroxides (LDHs) was investigated. A nitrate precursor was prepared by coprecipitaion at $\mathrm{pH} \mathrm{9.} \mathrm{An} \mathrm{attempt} \mathrm{to} \mathrm{intercalate} \mathrm{FP} \mathrm{by} \mathrm{direct}$ coprecipitation reaction led to a poorly crystalline $\mathrm{LDH}$ phase. The effects of $\mathrm{pH}$, aging time and anion concentration were studied and allowed to confirm that the best crystalline material, with high exchange extent, was obtained by carrying out the exchange at $25^{\circ} \mathrm{C}$ in $0 \cdot 1 \mathrm{M} \mathrm{FP}$ solution at $\mathrm{pH} 9$ with at least $20 \mathrm{~h}$ of aging time.
\end{abstract}

Keywords. Layered double hydroxide; intercalation; fluorophosphate; ion-exchange.

\section{Introduction}

Layered double hydroxides (LDHs), also called anionic (anion-exchanging) clays and hydrotalcite-like compounds (Allmann 1970) are layered compounds that are based in brucite, $\mathrm{Mg}(\mathrm{OH})_{2}$. They have a stacking of positively charged octahedral sheets with $\left[\mathrm{M}_{1-x}^{\mathrm{II}} \mathrm{M}_{x}^{\mathrm{III}}(\mathrm{OH})_{2}\right]^{x+}$ composition. $\mathrm{M}^{\mathrm{II}}$ and $\mathrm{M}^{\mathrm{III}}$ are divalent and trivalent metal ions, respectively. The net positive charge, due to substitution of trivalent by divalent metal ions, is balanced by an equal negative charge of interlayer solvated anions $\left[\mathrm{X}_{x / m}^{m-} \cdot n \mathrm{H}_{2} \mathrm{O}\right]^{x-}$. These compounds are usually abbreviated as [ $\left.\mathrm{M}^{\mathrm{II}}-\mathrm{M}^{\mathrm{III}}-\mathrm{X}\right]$. They are characterized by high charge density of sheets, modulated via the $\mathrm{M}^{\mathrm{II}} / \mathrm{M}^{\mathrm{III}}$ ratio. The hydrated anions in the interlayer spaces can be replaced with almost any desired anion, organic or inorganic, by utilizing simple ion exchange methods.

These compounds are of increasing interest because of their diverse potential applications in pharmacy, catalysis, food industry, polymers, electrochemistry, separation technology, etc. These applications are due to their layered structure, combined with their high anionic exchange capacity $\left(\approx 3\right.$ meq. $\left.\mathrm{g}^{-1}\right)$, compared to cationic clays such as smectite and vermiculite $\left(\approx 0.65-1.6\right.$ meq. $\left.\mathrm{g}^{-1}\right)$. The properties and applications of these hydrotalcite-type compounds have been the subject of a number of general and specialized reviews (Rives 2001; Braterman et al 2003).

\footnotetext{
*Author for correspondence (legrouri@aui.ma)
}

The present work forms part of a wider investigation aimed at understanding the mechanisms of interaction between LDHs and phosphates in view of LDH use in phosphate applications; Morocco being the first producer of these natural substances in the world-and environmental applications. FP is expected to behave somewhat in a similar way as the orthophosphate ions $\left(\mathrm{PO}_{4}^{3-}, \mathrm{HPO}_{4}^{2-}, \mathrm{H}_{2} \mathrm{PO}_{4}^{-}\right)$. The orthophosphate ions have the same geometrical structure as FP (tetrahedral). The difference lies in the electronic structure and geometrical distortion that is due to the longer $\mathrm{P}-\mathrm{F}$ bond (Serafini et al 1976). The $\mathrm{Zn}-\mathrm{Al}$ matrix was chosen in place of $\mathrm{Mg}-\mathrm{Al}$ in order to be able to carry out comparison between intercalation of FP and orthophosphates in the same matrix. Badreddine et al (1999) used Zn-Al for the study of orthophosphate intercalation. A comparison between the two matrices is planned now.

This paper presents synthesis and characterization of a fluorophosphate $\left(\mathrm{PO}_{3} \mathrm{~F}^{2-}, \mathrm{FP}\right)$ intercalated $\mathrm{LDH},[\mathrm{Zn}-\mathrm{Al}-$ $\mathrm{FP}$, directly and by ion exchange via a nitrate precursor, $\left[\mathrm{Zn}-\mathrm{Al}-\mathrm{NO}_{3}\right]$. Data on the preparation of the precursor and the final product, as well as their characterization by XRD, IR spectroscopy, SEM, microanalysis and thermal analyses are presented. The localization of FP in the interlayer space is discussed from the determination of the apparent interlayer spacing of the LDH, by XRD, IR and TG. The results obtained were compared with the other phosphate ions of the same geometry (Serafini et al 1976), which were intercalated in the same LDH matrix (Badreddine 1999).

The influence of anion concentration in solution, aging time, and $\mathrm{pH}$ were studied in order to determine the optimum conditions under which the exchanged clay is obtained with good crystallinity and high exchange extent. 


\section{Experimental}

\subsection{Materials}

All experiments were carried out under a stream of $\mathrm{N}_{2}$ in order to avoid, or at least minimize, the contamination by atmospheric $\mathrm{CO}_{2}$.

The $\left[\mathrm{Zn}-\mathrm{Al}-\mathrm{NO}_{3}\right]$ precursor was prepared by coprecipitaion at a constant $\mathrm{pH}$. A homogeneous mixture of $\mathrm{Zn}\left(\mathrm{NO}_{3}\right)_{2}$ and $\mathrm{Al}\left(\mathrm{NO}_{3}\right)_{3}$ aqueous solution, with a molar ratio of $x=$ 0.33 , was slowly introduced under stirring in a reactor which contained $250 \mathrm{~mL}$ of freshly de-ionized water. The $\mathrm{pH}$ of the solution was maintained constant at a value of 9 by the simultaneous addition of $1.0 \mathrm{M} \mathrm{NaOH}$ solution. The precipitate obtained was filtered, washed several times with water and then dried at room temperature.

Exchange reactions were carried out with $100 \mathrm{mg}$ of [ $\mathrm{Zn}-$ $\mathrm{Al}-\mathrm{NO}_{3}$ ] LDH suspended in $250 \mathrm{~mL}$ of $0 \cdot 1 \mathrm{M} \mathrm{PO}_{3} \mathrm{~F}^{2-}$ solution, which was stirred. The $\mathrm{pH}$ of the mixture was 9. The anion exchange reaction was achieved at ambient temperature $\left(25^{\circ} \mathrm{C}\right)$ with $40 \mathrm{~h}$ of aging time. The solids were separated from the solution by centrifugation and then washed several times with water. They were then dried in air at ambient temperature $\left(30^{\circ} \mathrm{C}\right)$.

Direct intercalation of FP ions by coprecipitation was used initially for the preparation of [Zn-Al-FP]. This method consisted of slowly adding a mixture of dilute solutions of $\mathrm{Zn}\left(\mathrm{NO}_{3}\right)_{2}$ and $\mathrm{Al}\left(\mathrm{NO}_{3}\right)_{3}$ into a reactor containing concentrated $\mathrm{PO}_{3} \mathrm{~F}^{2-}$ solution at a constant $\mathrm{pH}$ of 9, maintained by addition of $\mathrm{NaOH}$, at $25^{\circ} \mathrm{C}$ with $40 \mathrm{~h}$ of aging time.

\subsection{Methods}

XRD equipment used was a XPERT-MPD diffractometer. Samples of unoriented powder were exposed to copper $\mathrm{K}_{\alpha}$ radiation $(\lambda=0.15415 \mathrm{~nm})$. Measurement conditions were: $2 \theta$ range: $5-70^{\circ}$, step size: $0.08^{\circ} 2 \theta$ and step counting time: $4 \mathrm{~s}$. Data acquisition was effected on a DACO-MP microcomputer. Unit cell constants were calculated using a least-squares refinement.

IR absorption spectra were recorded on a Perkin-Elmer 16 PC FTIR spectrometer in the range $400-4000 \mathrm{~cm}^{-1}$, using $\mathrm{KBr}$ pellet method.

Samples in the form of a dry powder were sprinkled onto the surface of a very thin adhesive layer for examination in the SEM. They were then coated by vacuum deposition with gold in order to minimize the severe charging effects that proved to be characteristic of the materials examined. They were run on a Cambridge Stereo scan 360 microscope operated at an accelerating voltage of $20 \mathrm{kV}$.

$\mathrm{X}$-ray microanalysis was carried out on a Pentafet Oxford apparatus. For homogeneity, the samples were pressed into small disks and mounted on the sample holder. The results obtained constitute a mean of several analyses done on different points of the disk.
Thermogravimetric (TG) and differential thermal analyses (DTA) studies were performed with a Setaram TG-DSC 92 instrument. Curves were recorded on $20 \mathrm{mg}$ of the sample over a temperature range of up to $900^{\circ} \mathrm{C}$ at a heating rate of $5^{\circ} \mathrm{C} / \mathrm{min}$. The weights were corrected for the small effect of the gas flow as a function of temperature.

\section{Results and discussion}

Direct intercalation by coprecipitation reaction was not successful in producing a well crystalline LDH phase. This may be due to the random orientation of LDH sheets (figure 1). We report below on the study of the ion exchange starting with nitrate precursor.

\section{$3.1 X$-ray diffraction}

$\mathrm{XRD}$ pattern for the $\left[\mathrm{Zn}-\mathrm{Al}-\mathrm{NO}_{3}\right]$ precursor (figure 1) indicates that the sample, which consists of a single phase, is very well crystallized with its constituting crystallites of large size. This pattern is in agreement with that found for crystallites of the hydrotalcite-like minerals. The XRD powder data, refined on the hexagonal setting with a rhombohedral symmetry (space group: $R(-3) \mathrm{m}$ ), provided the lattice parameters for the sample: $a=0.307(5) \mathrm{nm}$ and $c=2.65(4) \mathrm{nm}$. The interlayer distance, $d=0.88(6) \mathrm{nm}$, is in accordance with a nitrate containing LDH (Badreddine 1999). The nitrate precursor was used for the preparation of FPcontaining LDH by ion exchange. The separate effects of FP concentration, aging time and $\mathrm{pH}$ were investigated in order to determine the optimum conditions for complete exchange and best crystallized compounds.

XRD of the solids obtained by ion exchange of nitrate by FP corresponds to that of a hydrotalcite-type material. Figures 2, 3 and 4 show XRD patterns for [Zn-Al-PF] LDHs. The lamellar structure of the material is preserved upon intercalation. However, the crystallinity is lowered, as attested by the broadening of the lines and decrease in their intensity. In addition, intercalation is observed to cause a displacement of the (003) line, denoting an increase in the interlamellar space which is due to the exchange of nitrate by the larger FP ions (Ookubo et al 1993, 1994; Reichele 1986; Badreddine et al 1998, 1999). The cell parameters for the best compound, in terms of crystallinity, were: $a=$ $0.307(8) \mathrm{nm}, c=3.45(7) \mathrm{nm}$ and the interlayer distance, $d=$ $1 \cdot 15(6) \mathrm{nm}$.

Study of the effect of FP concentration indicates that the best phase, in terms of crystallinity, was obtained for $0.1 \mathrm{M}$ (figure 2). The exchange can be considered as complete, since the lines of the nitrate containing LDH have disappeared. The presence of a shoulder for $0.01 \mathrm{M}$ at $d=0 \cdot 88(6)$ $\mathrm{nm}$ indicates that the exchange is only partial in this case. In addition, the interlayer distance varies slightly with ion concentration. The values are of the order of 1.0519, 1.1267 and $1.1500 \mathrm{~nm}$ for $0.01,0.05$ and $0.1 \mathrm{M}$, respectively. The 
product obtained at $0.01 \mathrm{M}$ concentration is interesting as it exhibits the third basal reflection of the FP-LDH when the first is not well developed. This may correspond to a mixture of two phases, nitrate and phosphate containing LDHs. Clay mixtures usually produce irrational series of diffraction lines that occupy intermediate positions with respect to the parent material according to the Mering rule.
The effect of aging time was investigated in solution with an FP concentration of $0.1 \mathrm{M}$. The evolution of the precipitate (figure 3 ) indicates that both the first lines, which correspond to (003) and (006) reflections vary in intensity. The ion exchange occurs and after $4 \mathrm{~h}$ of aging time, the [ $\mathrm{Zn}-\mathrm{Al}-\mathrm{FP}]$ phase coexists with the precursor. For the low aging time, there is an incomplete intercalation of the PF anion leading to

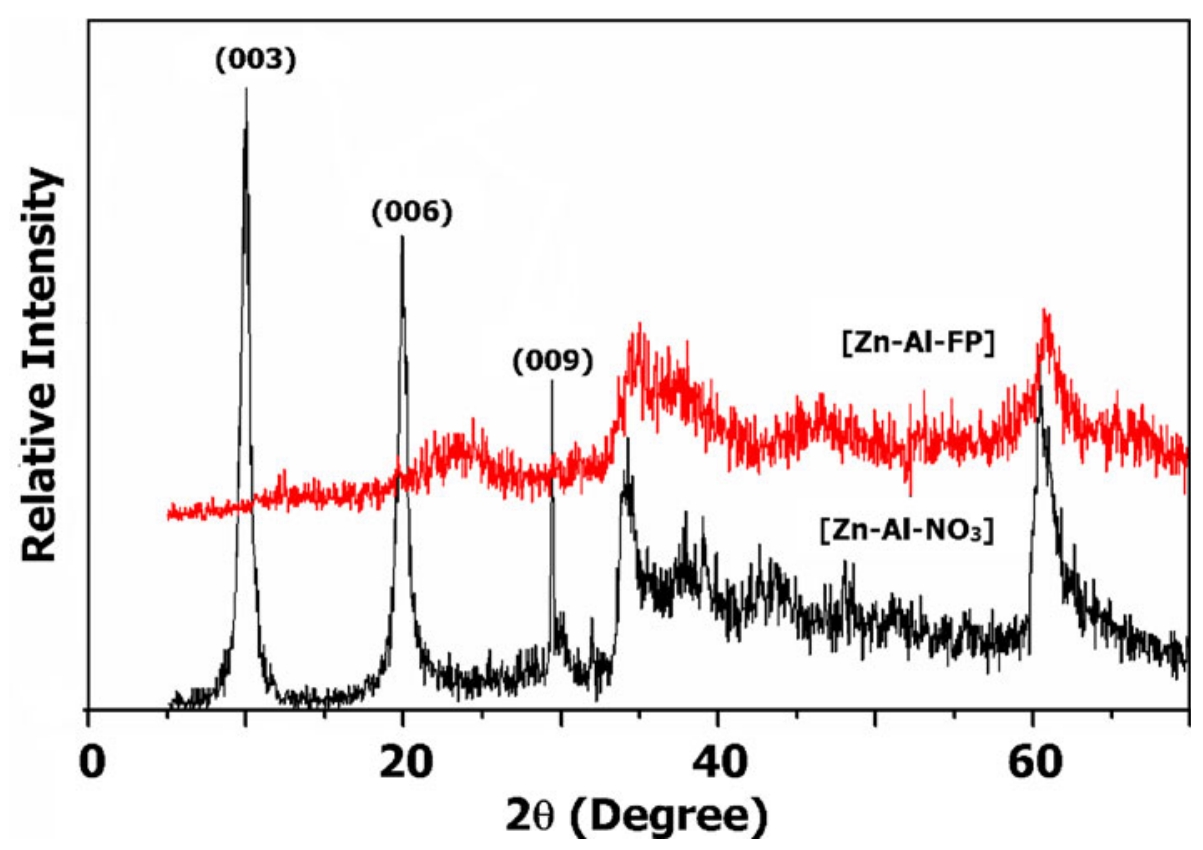

Figure 1. DRX patterns of $\left[\mathrm{Zn}-\mathrm{Al}-\mathrm{NO}_{3}\right]$ and $[\mathrm{Zn}-\mathrm{Al}-\mathrm{FP}]$ prepared by coprecipitation.

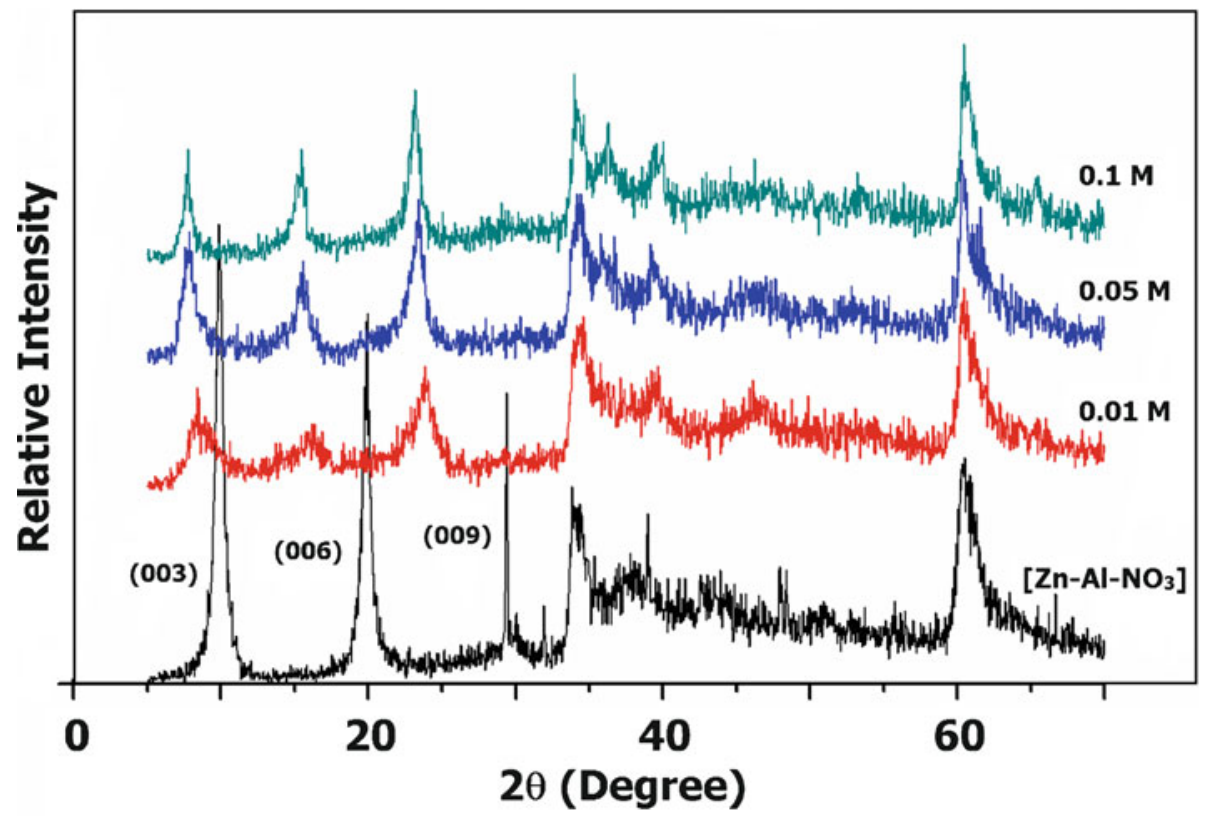

Figure 2. XRD patterns of FP-exchanged phases obtained in solutions with different FP concentrations. 


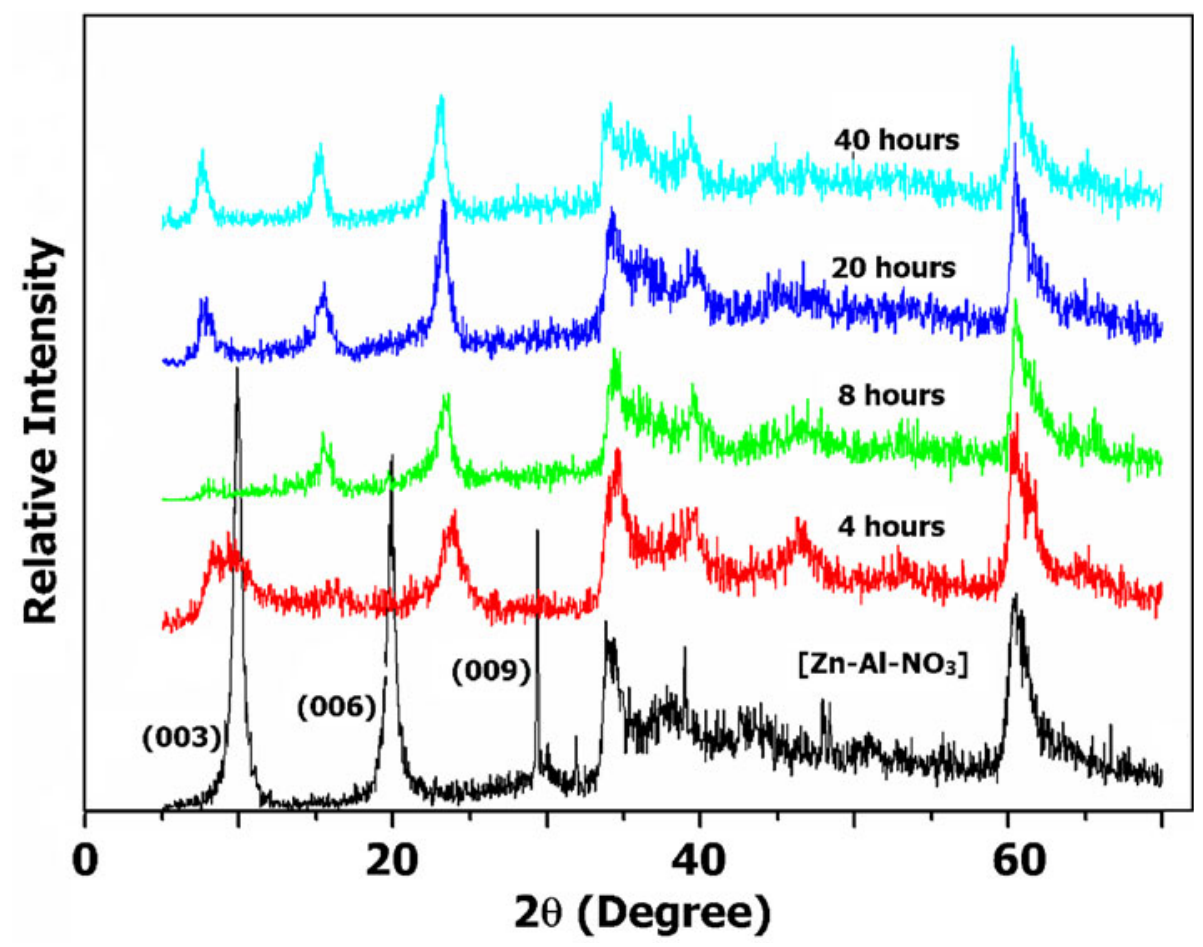

Figure 3. XRD patterns of FP-exchanged phases obtained in solutions with different aging times.

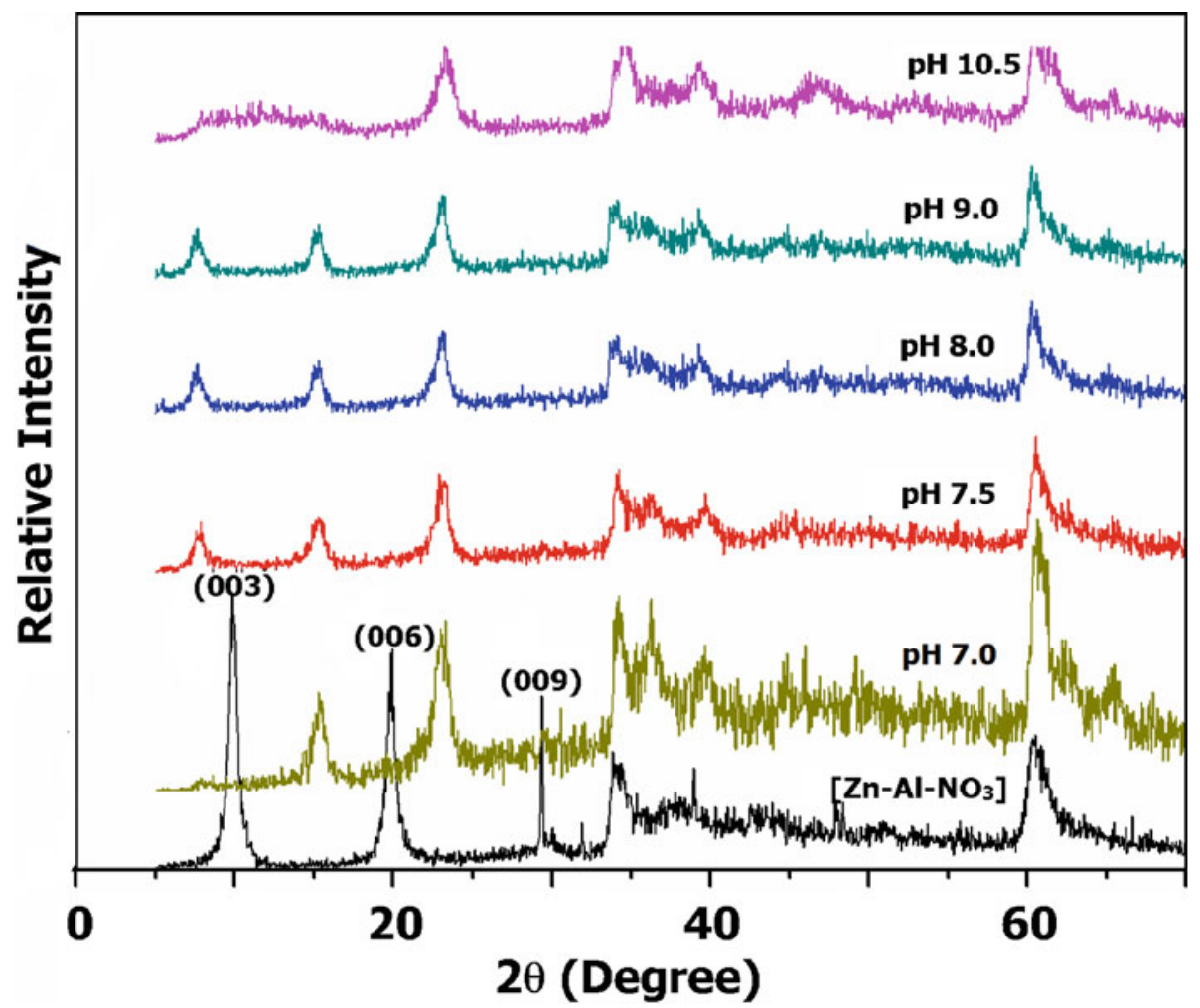

Figure 4. XRD patterns of FP-exchanged phases obtained in solutions with different $\mathrm{pH}$ values. 

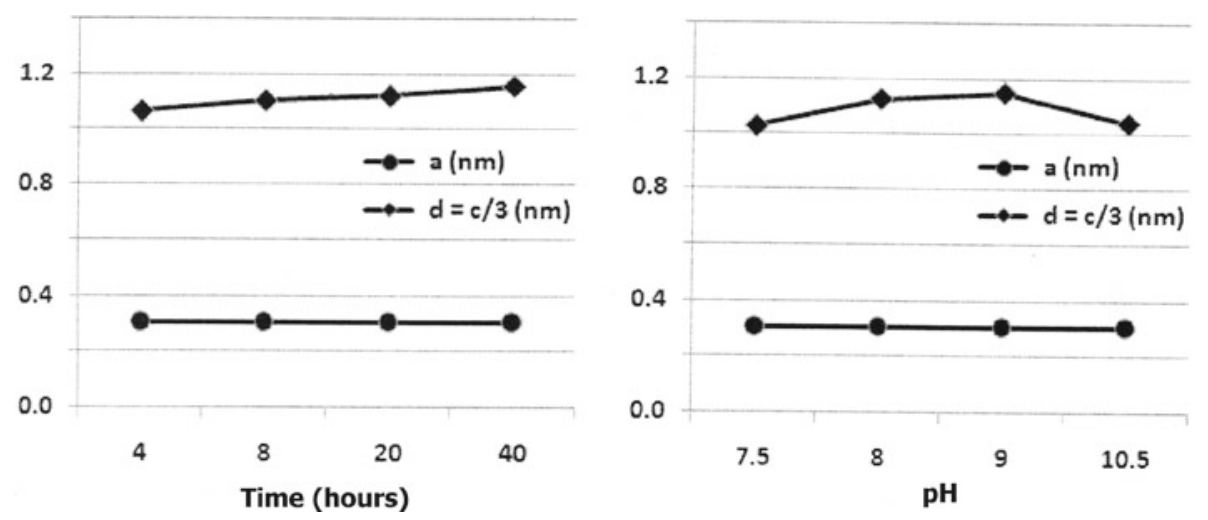

Figure 5. Evolution of cell parameters ' $a$ ' and interlayer space ' $d$ ' with aging time and with a solution $\mathrm{pH}$.

Table 1. Cell parameters of $\mathrm{Zn}-\mathrm{Al}-\mathrm{NO}_{3}$ and phosphate exchanged-phases.

\begin{tabular}{lll}
\hline Anion & $a(\mathrm{~nm})$ & $c(\mathrm{~nm})$ \\
\hline $\mathrm{NO}_{3}^{-}$ & $0 \cdot 307$ & 2.65 \\
$\mathrm{PO}_{3} \mathrm{~F}^{2-}$ & $0 \cdot 307$ & 3.45 \\
$\mathrm{H}_{2} \mathrm{PO}_{4}^{-}$ & $0 \cdot 306$ & 3.56 \\
$\mathrm{HPO}_{4}^{2-}$ & $0 \cdot 307$ & 3.19 \\
$\mathrm{PO}_{4}^{3-}$ & $0 \cdot 307$ & 2.79 \\
\hline
\end{tabular}

the turbostatic stacking of the layers and lower crystallinity affecting thus the intensity of the (003) line. Higher aging time allows for complete intercalation and better crystallinity as well an increased intensity of the (003) line. After $8 \mathrm{~h}$ of aging time, XRD indicates the presence of a single phase with well-defined reflection lines.

This shows that the exchange takes place by staging and rearrangement of the matter. The shift of (003) and (006) lines towards higher interlayer distances might be attributed to the anion orientation and to the amount of anions in the interlayer space. These results indicate that the most preferred time for well-crystallized phase formation is within a range of $20-40 \mathrm{~h}$. Below $8 \mathrm{~h}$, there is only a partial exchange. Figure 5 shows the evolution of cell parameters as a function of aging time.

Study of the effect of $\mathrm{pH}$, with an FP concentration of $0.1 \mathrm{M}$ (figure 4), shows that the best crystallinity is obtained for a $\mathrm{pH}$ in the range of 7.5-9. Above 10 and below 7, the (003) line disappears and the crystallinity is lowered. Figure 5 shows evolution of the cell parameters $(a, c)$ and interlamellar space $(d)$ with $\mathrm{pH}$. The highest interlayer space is obtained for a range of $\mathrm{pH}$ between 8 and 9 . The lattice parameter $a$, which is related to the metal-metal interatomic distance within layers, is not affected by the $\mathrm{pH}$ variation, as expected.

The cell parameters for the optimized sample compare well with those of orthophosphate (table 1). The FPintercalated LDH exhibits an interlayer distance that is

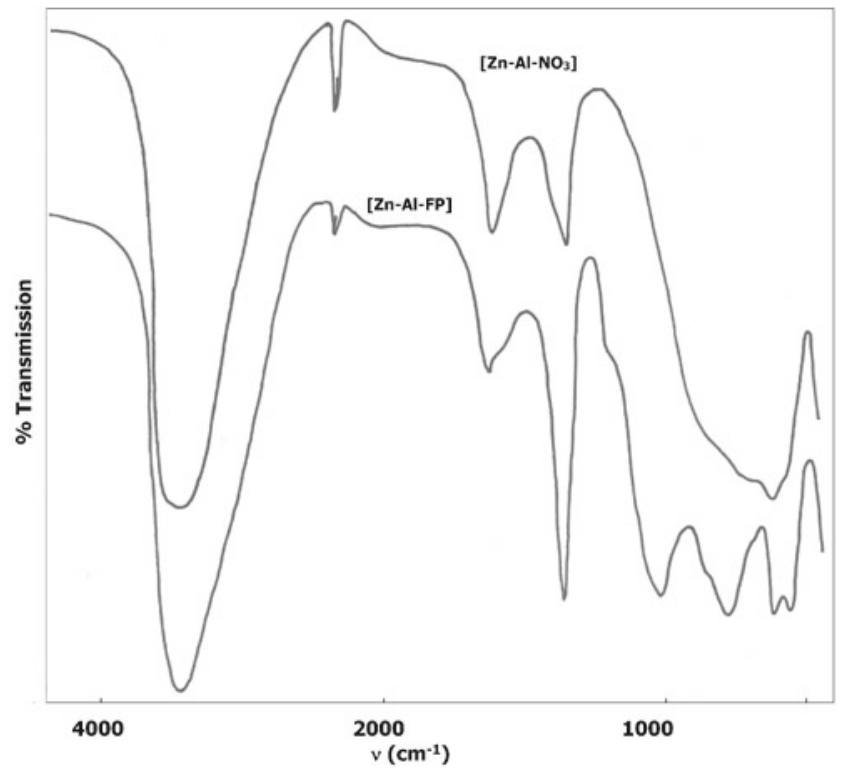

Figure 6. IR spectra of $\left[\mathrm{Zn}-\mathrm{Al}-\mathrm{NO}_{3}\right]$ and $[\mathrm{Zn}-\mathrm{Al}-\mathrm{FP}]$.

between those of $\mathrm{H}_{2} \mathrm{PO}_{4}$ and $\mathrm{HPO}_{4}$. This can only be explained by the electronic factors, given that the progressive substitution of oxygen by fluorine in the orthophosphate leads to smaller size of tetrahedron (Serafini et al 1976).

\subsection{Infrared spectroscopy}

The FP-nitrate exchange is supported by IR results. IR spectrum of $[\mathrm{Zn}-\mathrm{Al}-\mathrm{FP}]$ compared with that of $[\mathrm{Zn}-\mathrm{Al}-$ $\mathrm{NO}_{3}$ ] precursor is illustrated in figure 6. It can be noted that the lattice vibrations are preserved and the new bands imply that the FP anion is present. The absorption centred at $3448 \mathrm{~cm}^{-1}$, which results from the stretching vibration of hydroxyl groups and water molecules, is appreciably broadened by the presence of FP anion. This may be attributed to the interaction of the anion with water molecules as well as the interlayer matter disorder (Bish and Brindley 1977). 


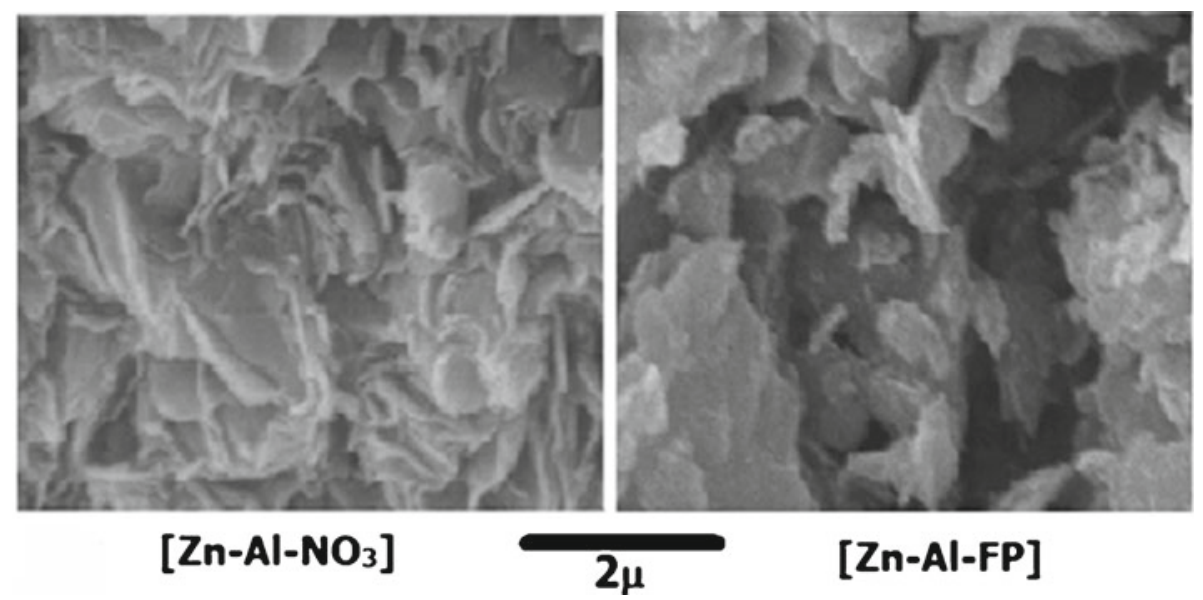

Figure 7. SEM photographs of $\left[\mathrm{Zn}-\mathrm{Al}-\mathrm{NO}_{3}\right]$ and $[\mathrm{Zn}-\mathrm{Al}-\mathrm{FP}]$ obtained in solution of $\mathrm{pH} 9$.

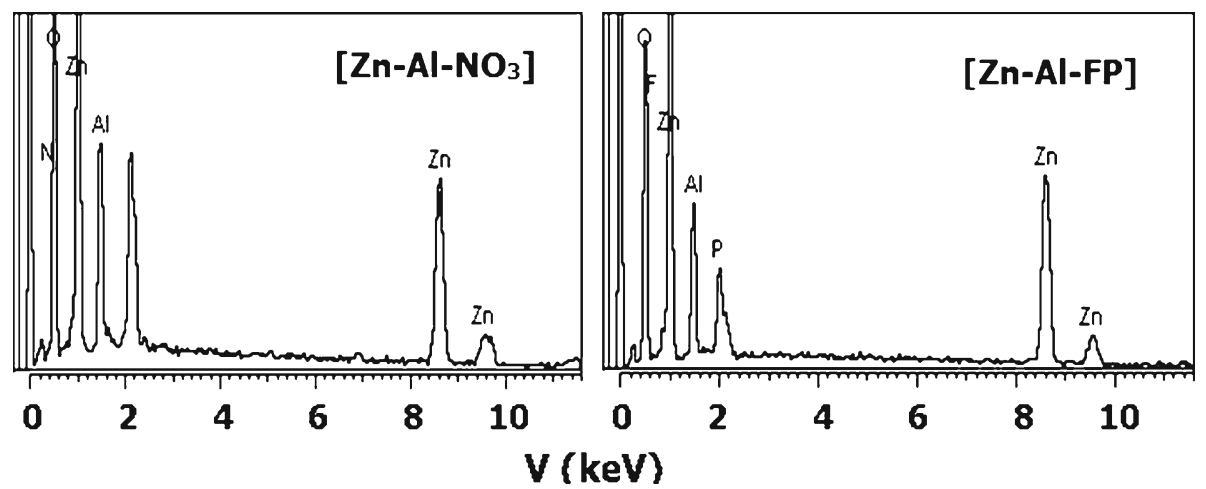

Figure 8. X-ray microanalysis spectra of $\left[\mathrm{Zn}-\mathrm{Al}-\mathrm{NO}_{3}\right]$ and $[\mathrm{Zn}-\mathrm{Al}-\mathrm{FP}]$ obtained in a solution of $\mathrm{pH} 9$.

The absorption at $1637 \mathrm{~cm}^{-1}$ is assigned to the bending vibration of water. The proof for the presence of fluorophosphate groups results from their characteristic vibrations: $1200,1023,780,617$ and $550 \mathrm{~cm}^{-1}$ corresponding to $\delta(\mathrm{P}-\mathrm{OH}), v_{1}(\mathrm{P}-\mathrm{O}), v(\mathrm{P}-\mathrm{F}), v_{2}(\mathrm{P}-\mathrm{O})$ and $v_{3}(\mathrm{P}-\mathrm{O})$ vibrations, respectively (Durand et al 1978). The band at $1363 \mathrm{~cm}^{-1}$, whose intensity increases after exchange, is assigned to the carbonate ion.

\subsection{Scanning electron microscopy and microanalysis}

The examination of the parent and FP-intercalated materials by SEM (figure 7) reveals that the crystals present almost the same morphological features. They tend to result from the superposition of several leaflets with dimensions of the particles being about $7 \mu \mathrm{m}$ for $\left[\mathrm{Zn}-\mathrm{Al}-\mathrm{NO}_{3}\right]$ and $5 \mu \mathrm{m}$ for [Zn-Al-FP]. These particles constitute of crystallites whose sizes are of $\sim 1.2 \times 1.4$ and $1.0 \times 0.4 \mu \mathrm{m}$, respectively. The small morphological alteration of the layers, upon exchange, can be due to the decrease in crystallinity observed by XRD in the sample.
The microprobe analysis of the sample before and after exchange was carried out on different crystals and for separate points in the same crystal for each phase. The spectrum of the parent material exhibits characteristic emissions for zinc, aluminium and nitrogen while that of the intercalated sample presents, in addition to the emissions of zinc and aluminium, only those of fluorine and phosphorus (figure 8) confirming the nitrate-FP ion exchange. This characterization also suggests that the samples have a homogeneous chemical composition, whose average is given below:

$$
\begin{gathered}
{\left[\mathrm{Zn}_{2.05} \mathrm{Al}(\mathrm{OH})_{6 \cdot 05}\right]\left[\left(\mathrm{NO}_{3}\right)_{1.05} ; 1 \cdot 22 \mathrm{H}_{2} \mathrm{O}\right] \text { and }} \\
{\left[\mathrm{Zn}_{1.95} \mathrm{Al}(\mathrm{OH})_{5.9}\right]\left[\left(\mathrm{PO}_{3} \mathrm{~F}\right)_{0.5} ; 1.43 \mathrm{H}_{2} \mathrm{O}\right]}
\end{gathered}
$$

\subsection{Thermal analyses}

TG and DTA curves obtained for both $\left[\mathrm{Zn}-\mathrm{Al}-\mathrm{NO}_{3}\right]$ and [Zn-Al-FP] are reported in figure 9. The thermal evolution of the solids takes place in consecutive stages with weight 


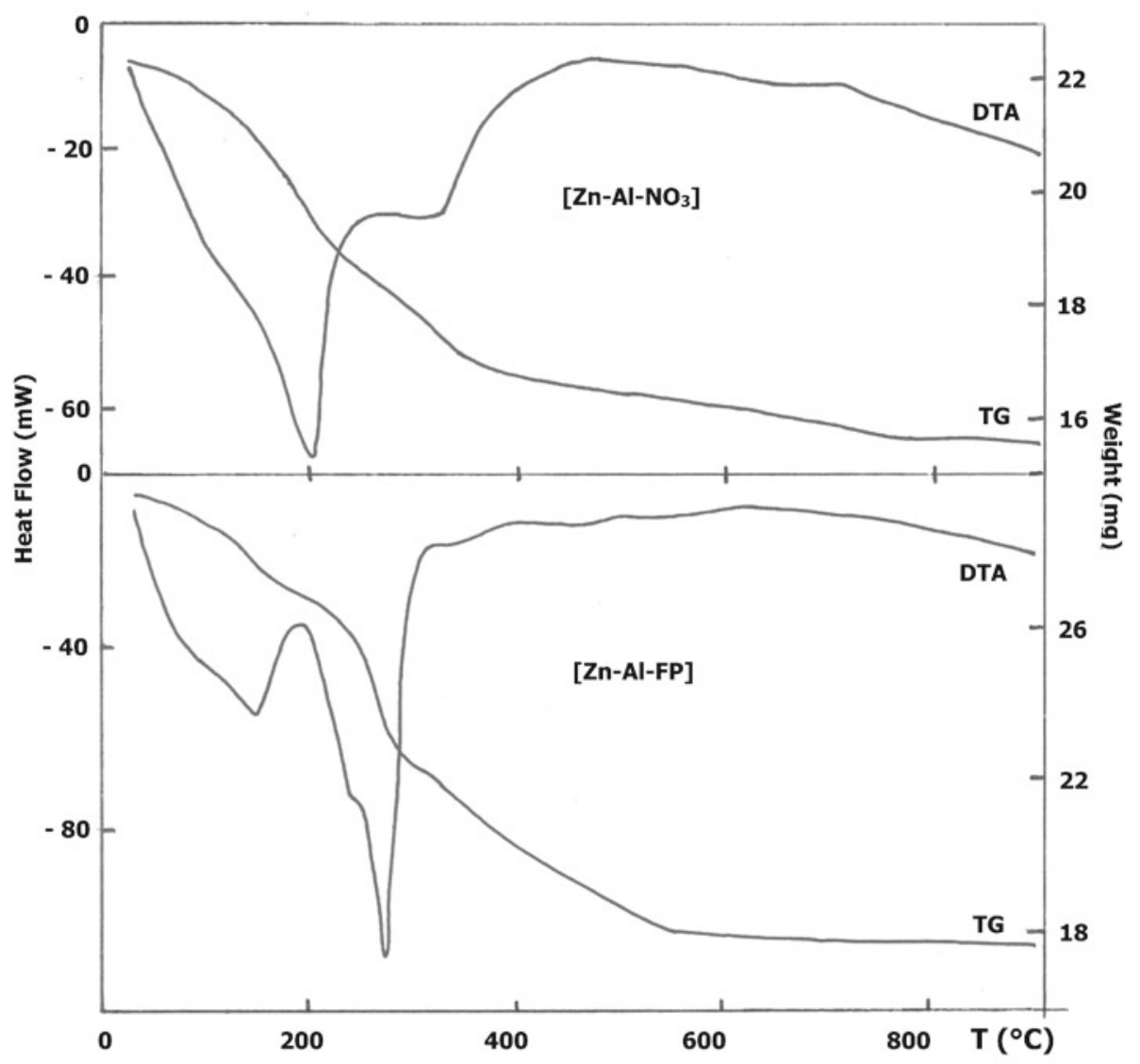

Figure 9. DTA and TG curves of $\left[\mathrm{Zn}-\mathrm{Al}-\mathrm{NO}_{3}\right]$ and $[\mathrm{Zn}-\mathrm{Al}-\mathrm{FP}]$.

losses for which the inflection points coincide with the temperatures corresponding to minima and maxima in DTA traces.

The thermogram corresponding to the precursor is comparable to previous data for LDH-like materials (El Malki et al 1989; Khaldi et al 1998). It presents a first mass loss (8.8\%), which takes place in two consecutive stages, by heating up to $165^{\circ} \mathrm{C}$, and can be attributed to the removal of adsorbed and interlayer water. It is accompanied by an endothermic effect at $\sim 120^{\circ} \mathrm{C}$ and a shoulder at $100^{\circ} \mathrm{C}$. The second loss $(15.2 \%)$ observed between $180^{\circ} \mathrm{C}$ and $350^{\circ} \mathrm{C}$, with an endothermic peak at $275^{\circ} \mathrm{C}$, corresponds to the dehydroxylation and collapse of the layered structure. Beyond $350{ }^{\circ} \mathrm{C}$, the third loss $(16.5 \%)$, with a large exothermic signal at $510^{\circ} \mathrm{C}$, may correspond to the elimination of the nitrate ions (De Roy et al 1988).

The thermal evolution of FP-intercalated LDH takes place in three consecutive stages. The first weight loss of $14.8 \%$, which begins as soon as heating is applied with one endothermic effect at $\sim 150^{\circ} \mathrm{C}$ with a shoulder at about $80^{\circ} \mathrm{C}$, was attributed to the loss of adsorbed and interlayer water molecules. The second weight loss between 210 and $430{ }^{\circ} \mathrm{C}$ $(\sim 11.2 \%)$, with an endothermic peak at $275^{\circ} \mathrm{C}$ and a shoulder at $240^{\circ} \mathrm{C}$, was assigned to the dehydroxylation of the brucite-like layers. These two first stages are similar to those previously reported for hydrotalcite-like materials (Rey and Fornés 1992).

\section{Conclusions}

The $[\mathrm{Zn}-\mathrm{Al}-\mathrm{FP}] \mathrm{LDH}$ phase can be prepared from a $[\mathrm{Zn}-$ $\mathrm{Al}-\mathrm{NO}_{3}$ ] precursor, obtained by a coprecipitaion method at a constant $\mathrm{pH}$, by ion exchange reaction in a $\left(\mathrm{NH}_{4} \mathrm{PO}_{3} \mathrm{~F} \cdot \mathrm{H}_{2} \mathrm{O}\right)$ solution. The effects of $\mathrm{pH}$, aging time and anion concentration were studied in order to determine the optimum conditions under which an FP-intercalated clay is obtained with good crystallinity and high exchange extent.

XRD and IR spectroscopy revealed that, in all cases, the crystallinity of $[\mathrm{Zn}-\mathrm{Al}-\mathrm{FP}]$ phases is lower than that of the precursor. Ion exchange was also observed to cause a certain disorder in the layers without the destruction of the lamellar structure of the material.

The best crystalline material, with high exchange extent, was obtained by carrying out the exchange at $25^{\circ} \mathrm{C}$ in $0.1 \mathrm{M}$ FP solution at $\mathrm{pH} 9$ with at least $20 \mathrm{~h}$ of aging time.

Characterization of a sample, prepared under these conditions, by $\mathrm{X}$-ray microanalysis also proved that the ion exchange had taken place. 
Thermal analyses of the optimised [Zn-Al-FP] phase led to the loss of adsorbed and interlayer water, as well as to dehydroxylation of the layers below $240^{\circ} \mathrm{C}$. The decomposition of the fluorophosphate anion by combustion reactions was observed after this point.

\section{References}

Allmann R 1970 Chimia 2499

Badreddine M 1999 Thesis, Cadi Ayyad University, Marrakech, Morocco

Badreddine M, Khaldi M, Legrouri A, Barroug A, Chaouch M, De Roy A and Besse J P 1998 Mater. Chem. Phys. 52235

Badreddine M, Khaldi M, Legrouri A, Barroug A, Chaouch M, De Roy A and Besse J P 1999 Mater. Lett. 38391

Bish D L and Brindley G W 1977 Am. Mineral. 62458
Braterman P S, Xu Z P and Yarberry F 2003 in Handbook of Layered Materials (eds) S M Auerbach et al (New York: Marcel Dekker)

De Roy A, Vernay A M, Besse J P and Thomas G 1988 Analysis 16 409

Durand J, Beys L, Hillaire P, Aleonard S and Cot L 1978 Spectrochim. Acta A34 123

El Malki K, De Roy A and Besse J P 1989 Eur. J. Solid State Inorg. Chem. 26339

Khaldi M, Badreddine M, Legrouri A, Chaouch M, Barroug A, De Roy A and Besse J P 1998 Mater. Res. Bull. 331835

Ookubo A, Ooi K and Hayashi H 1993 Langmuir 1418

Ookubo A, Ooi K and Tani F 1994 Langmuir 10407

Reichele W T 1986 Solid State Ionics 22135

Rey F and Fornés V 1992 J. Chem. Soc. Faraday Trans. 88233

Rives V 2001 Layered double hydroxides: Present and future (New York: Nova Sci. Pub., Inc.)

Serafini A, Labarre J-F, Granier W and Cot L 1976 J. Chim. Phys. 173 